УДК 351.862.2

\section{Слісєєв Валерій,} канд. техн. наук, доц.

ORCID iD 0000-0002-2427-0860

E-mail: elisev1941@ukr.net

\section{Пруський Андрій,}

канд. техн. наук, доц.

ORCID iD 0000-0002-9132-7070

E-mail:prusskiy@ukr.net

\section{Тищенко Василь,}

канд. наук держ.упр., доц.

ORCID iD 0000-0001-7505-1599

E-mail: tva_5555@ukr.net

Власенко Свген

ORCID iD 0000-0002-9619-1504

E-mail: geniy20091@ukr.net

\title{
МЕТОДИКА РОЗРАХУНКУ МАТЕРІАЛЬНИХ РЕЗЕРВІВ ЯК ІНСТРУМЕНТ МЕХАНІЗМУ ДЕРЖАВНОГО УПРАВЛІННЯ СИЛАМИ ЦИВІЛЬНОГО ЗАХИСТУ
}

\author{
https://doi.org/10.32689/2618-0065-2020-4(6)-122-142
}

Анотація. Важливим елементом управлінської діяльності є підготовка та прийняття обгрунтованих управлінських рішень Ефективність функціонування єдиної державної системи цивільного захисту (СДСЦЗ) в цілому визначається оперативністю дій сил цивільного захисту (ЦЗ). Сили цивільного захисту - це аварійно-рятувальні формування, спеціалізовані служби та інші формування цивільного захисту, призначені для проведення аварійно-рятувальних та інших невідкладних робіт (АРІНР) 3 ліквідації наслідків надзвичайних ситуацій (НС). Тривалість проведення різного виду робіт залежить від достатнього запасу матеріального резерву, що використовується при виконанні робіт, та визначає час ліквідації НС та ії наслідків, тим самим 


\section{Науковий вісник: Державне управління № 4(6)2020}

впливає на кількість людських жертв і об'єм матеріальних збитків від НС. У науковій статті на основі аналізу завдань визначених Кодексом цивільного захисту а також дій органів управління та сил цивільного захисту у надзвичайних ситуаціях пропонується математичний апарат визначення необхідних (достатніх) матеріальних резервів для підвищення ефективності дій підрозділів сил цивільного захисту при ліквідації наслідків надзвичайних ситуацій як інструмент механізму державного управління силами цивільного захисту. Матеріальні резерви необхідні для забезпечення експлуатації та ремонту техніки та озброєння можуть утворювати комплекти матеріальних резервів або матеріальні резерви за окремими типами елементів на складах. Комплектні матеріальних резервів, у свою чергу, можна поділити на об'єктові (на один тип техніки) та групові (на групу однотипних об’єктів техніки). У статті розроблено математичний апарат розрахунку матеріальних резервів необхідних для забезпечення експлуатації техніки та озброєння при виконанні аварійно-рятувальних та інших видів робіт. Для оцінки впливу матеріальних резервів на ефективність функціонування підрозділів сил цивільного захисту при ліквідації НС та їх наслідків використовуються деякі показники надійності озброєння.

Ключові слова: сили цивільного захисту, матеріальні резерви, показники готовності, об’єкти озброєння, ймовірність.

Постановка проблеми. В умовах проведення в Україні адміністративної реформи особливої актуальності набуває проблема підвищення ефективності державного управління зокрема, системи органів державної влади всіх рівнів. Проблема ефективності роботи органів управління в багатьох випадках зводиться до ефективності праці службовців апарату, зміни їх чисельності, якості, затрат часу тощо. Але за такого вирішення проблеми поза увагою науковців і практиків залишається найважливіше удосконалення самого механізму управління в органах державної влади, зокрема, в обласних державних адміністраціях [5]. Враховуючи викладене, авторами статті пропонується методика розрахунку матеріальних резервів як інструмент механізму державного управління силами цивільного захисту для ліквідації надзвичайних ситуацій. 
Науковий вісник: Державне управління № 4(6)2020

Проведення робіт 3 порятунку i надання допомоги постраждалому населенню та відновлення зруйнованих об’єктів вимагає наявності значної кількості спеціальної техніки, матеріалів, палива, фахівців та ін. Тривалість проведення різного виду робіт залежить від достатнього запасу матеріального резерву, що використовується при виконанні робіт, та визначає час ліквідації НС та ії наслідків, тим самим впливає на кількість людських жертв і об'єм матеріальних втрат від НС $[4,11]$. Тому питання управління матеріальними резервами $є$ актуальним.

Аналіз останніх досліджень та публікацій. У попередніх наукових дослідженнях $[6,7,9]$ окремо розглядалися питання забезпечення матеріальними резервами підрозділів сил цивільного захисту 3 метою їх ефективного функціонування при виконанні завдань з ліквідації НС та їх наслідків на достатньому (заданому) рівні готовності. Але, недостатньо дослідженими залишилися питання розробки комплексної моделі яка б дозволяла визначити усі необхідні види та обсяги матеріальних резервів.

Метою статті $\epsilon$ : на підставі попередніх наукових досліджень визначити інструмент державного управління та математичний апарат розрахунку різних видів матеріального резерву при заданих показниках достатності резерву з метою підвищення ефективності функціонування об'єктів озброєння, підрозділів сил Ц3 при виконанні завдань 3 ліквідації наслідків НС, а також в цілому СДСЦЗ.

\section{Виклад основного матеріалу дослідження.} Відповідно до ст. 98 Кодексу цивільного захисту України [1] матеріальні резерви для запобігання і ліквідації наслідків НС створюються центральним органом виконавчої влади, що забезпечує формування та реалізує державну політику у сфері цивільного захисту (оперативний матеріальний резерв), іншими центральними органами виконавчої влади (відомчий матеріальний резерв), місцевими державними адміністраціями, органами місцевого самоврядування (регіональний та місцевий 
Науковий вісник: Державне управління № 4(6)2020

матеріальні резерви) та суб'єктами господарювання (об'єктовий матеріальний резерв).

Матеріальний резерв це запас будівельних і пальномастильних матеріалів, лікарських засобів та виробів медичного призначення, продовольства, техніки, технічних засобів та інших матеріальних цінностей, призначених для запобігання і ліквідації наслідків надзвичайних ситуацій, надання допомоги постраждалому населенню, проведення невідкладних відновлювальних робіт і заходів [2, 10].

Для забезпечення ефективного функціонування підрозділів сил цивільного захисту при виконанні завдань 3 ліквідації НС та їх наслідків на достатньому (заданому) рівні готовності з урахуванням наявності різних видів матеріальних резервів необхідно розробити моделі які б дозволяли визначити необхідні види та обсяги матеріальних резервів.

Матеріальні резерви (MP) необхідні для забезпечення експлуатації та ремонту техніки та озброєння можуть утворювати комплекти МР або MP за окремими типами елементів на складах (MP_C). Комплектні МР, у свою чергу, можна поділити на об'єктові (на один тип техніки) MP_О та групові (на групу однотипних об'єктів техніки) MP_Г.

Для оцінки впливу матеріальних резервів на ефективність функціонування підрозділів оперативно-рятувальної служби цивільного захисту (ОРСЦЗ) при ліквідації НС та їх наслідків розглянемо деякі показники надійності озброєння підрозділів OPC.

Згідно 3 [3] показниками оцінки готовності та працездатності об'єктів озброєння є:

готовність - властивість об'єкта, бути здатним виконувати потрібні функції в заданих умовах у будь-який час чи протягом заданого інтервалу часу за умови забезпечення необхідними зовнішніми ресурсами;

працездатність - стан об'єкту, який характеризується його здатністю виконувати усі потрібні функції; 
стаціонарний коефіuуієнт готовності: К г - значення коефіцієнта готовності визначене для умов роботи об'єкта коли середній параметр потоку відмов i середня тривалість відновлення залишаються сталими;

середній наробіток до відмови Т о - математичне очікування наробітку об'єкта до першої відмови;

середня тривалість відновлення $T_{B}$ - математичне очікування часу відновлення працездатного стану об'єкта після відмови.

Математична модель розрахунку $M P_{-} C$.

Метою розроблення математичної моделі розрахунку складського матеріального резерву (MP_C) $\epsilon$ можливість раціонального визначення об'єму матеріального резерву для забезпечення запобігання та ліквідації надзвичайних ситуацій та їх наслідків на достатньому рівні.

Рівень достатності МР_C оцінюється індивідуально по кожному типу запасних елементів у резерві (наприклад: складові спеціального майна, елементи пожежно-технічного озброєння та ін.) з використанням коефіцієнта забезпеченості ( $\left.\boldsymbol{K}_{\text {oci }}\right)$ (форм. 1)

Група 3 довільного числа працюючих елементів, включених по послідовної схеми надійності, маючих однакову та постійну інтенсивність відмов, має, згідно [8], ймовірність безвідмовної роботи $(\boldsymbol{P}(\boldsymbol{t}))$ за час $\boldsymbol{t}$ (форм. 2)

$$
K_{o c i}(x)=\mathrm{P}_{\text {Дi }}(x) * 100 \% \text {, }
$$

де, $\mathrm{P}_{\text {ді }}(x)$ - імовірність достатності елементів $i$-го типу в MP_C;

$x$ - загальна кількість елементів у MP_C.

$$
P(t)=e^{-n \lambda t}=e^{-a}
$$

де, $n$ - число працюючих елементів;

$\lambda$ - інтенсивність відмов; 
$a=n \lambda t-$ середнє число відмов у групі за час $t$.

Надаючи такій групі резерв із $(\boldsymbol{x})$ елементів, можна збільшити ймовірність безвідмовної роботи $(\boldsymbol{P}(\boldsymbol{t}))$ до значення (форм.3).

$$
P(t)=e^{-a} \sum_{i=1}^{x} \frac{a^{i}}{i !}
$$

Якщо в цій формулі час $t$ зробити рівним періоду поповнення MP_C $(\mathrm{t}=\mathrm{Tc})$, то чисельно ймовірність $(\boldsymbol{P}(\boldsymbol{t}))$ буде являти собою ймовірність того, що за час $\left(\mathbf{T}_{\mathbf{C}}\right)$ число вимог на резервні елементи не перевищить числа $(\boldsymbol{x})$, тобто ймовірність достатності $(\boldsymbol{x})$ резервних елементів дорівнює $\left(\boldsymbol{P}_{д}(\boldsymbol{x})\right)$ (форм.4).

$$
P_{\text {д }}(x)=e^{-a} \sum_{i=1}^{x} \frac{a^{i}}{i !},
$$

Форм. 4 використовується для розрахунку числа резервних елементів будь-якого типу в МР_C.

Основними вихідними даними для розрахунку є:

1) чисельні значення заданого коефіцієнта забезпеченості для елементів кожного типу $-\left(\boldsymbol{K}_{\text {oci }}(\boldsymbol{x})\right)$

2) середня кількість відмов елементів $i-$ го типу за період поповнення MP_C $-\left(\boldsymbol{a}_{i}\right) \quad(i=1, m)$, де $(\boldsymbol{m})-$ кількість типів елементів в MP_C

Якщо значення $\left(\boldsymbol{a}_{i}\right)$ безпосередньо не відомі, то їх треба визначити, підсумовуючи середню кількість відмов елементів по кожному із $(\boldsymbol{k})$ об'єктів (форм.5)

У свою чергу, $\left(\boldsymbol{a}_{i j}\right)$ знаходиться по числу елементів цього типу в кожному із об'єктів, витратам ресурсу систем $\left(\mathbf{T}_{p j}\right)$ за період поповнення MP_C ( $\left.\mathbf{T}_{\mathbf{c}}\right)$ та інтенсивності відмов елементів $i$-го типу на $j$-му об'єкті ( $\left.\lambda_{i j}\right)$ (форм.6). 
Науковий вісник: Державне управління № 4(6)2020

$$
a_{i}=\sum_{j=1}^{k} a_{i j},
$$

де, $k$ - число об'єктів, у яких працюють елементи i- го типу;

$a_{i j}-$ середня кількість відмов елементів $i-$ го типу на $j-$ му об'єкті.

$$
a_{i j}=\lambda_{i j} n_{i j} T_{P j}
$$

де, $n_{i j}$ - число елементів $i$-го типу на $j$-му об'єкті.

За заданим значенням ( $\left.\boldsymbol{K}_{\boldsymbol{o c}}\right)$ визначають ймовірність достатності елементів $i$-го типу (форм.7).

$$
P_{\text {Дi }}(a, x)=\frac{K_{o c i}}{100} .
$$

Далі за ймовірності достатності $\left(\boldsymbol{P}_{\text {ді }}(\boldsymbol{a}, \boldsymbol{x})\right)$ і середній кількості відмов елементів $\left(\boldsymbol{a}_{\boldsymbol{i}}\right)$ визначаємо число резервних елементів $i$-го типу, при якому виконується умова (форм. 8).

$$
P_{\text {Д }}\left(a=a_{i}, x=x_{i}-1\right) \leq P_{\text {Дi }}(a, x) \leq P_{\text {Д }}\left(a=a_{i}, x=x_{i}\right),
$$

Де число $\left(\boldsymbol{x}_{\boldsymbol{i}}\right)$ знаходять як найменш можливе, при якому фактична ймовірність достатності виявляється не менш заданої.

Після цього повторюють дії по розрахунку ймовірності достатності та числа резервних елементів для 2-го, 3-го й наступних типів елементів. 
Науковий вісник: Державне управління № 4(6)2020

Після розрахунків по усім типам елементів визначаємо загальний об'єм складського матеріального резерву MP_C $\left(\boldsymbol{X}_{\boldsymbol{c}}\right)$ (форм. 9).

$$
X_{C}=\sum_{i=1}^{m} x_{i},
$$

де, $m$ - кількість типів елементів в MP_C

Математична модель розрахунку MP_O.

Згідно [3] стаціонарний коефіцієнт готовності об'єкту озброєння визначається за форм. 10.

$$
K_{\Gamma}=\frac{T_{0}}{T_{0}+T_{B}},
$$

де, $T_{\mathrm{O}}$ - середній наробіток до відмови об'єкту;

$T_{B}$-середня тривалість відновлення працездатного стану об'єкту після відмов.

Час відновлення $\left(\boldsymbol{T}_{\boldsymbol{B}}\right)$ зручно розділити на дві складові: час доставки резервного елементу $\left(\boldsymbol{T}_{\boldsymbol{\partial}}\right)$ і час ремонту $\left(\boldsymbol{T}_{\boldsymbol{P}}\right)$, тобто інтервал часу витрачений на всі інші операції відновлення працездатності об'єкту. У такому випадку:

$$
T \beta=T_{p}+T_{\partial}
$$

Що стосується часу доставки резервного елемента, то він $\epsilon$ випадковою величиною й залежить в основному від організації служби постачання, віддалення об'єкту озброєння від складів матеріального резерву, засобів транспорту, а також, в деякій мірі, від типу елемента, що доставляється.

Згідно [8] для опису процесу роботи й відмов елементів приймемо експонентний закон надійності. Будучи найбільш 
простим, цей закон задовільно описує процес відмов більшості елементів, застосовуваних в техніці та озброєнні.

Для прийнятої моделі стаціонарний коефіцієнт готовності об’єкту визначається за форм. 12 .

$$
K_{\Gamma}(x)=\frac{T_{0}}{T_{0}+T_{p}+T_{\partial} \cdot P(x)},
$$

де, $P(x)$ - імовірність простою об'єкту озброєння через недостачу резервних $(\boldsymbol{x})$ елементів у комплекті МР об’ єкту.

Випадок, коли $(x=0)$ відповідає повній відсутності резервних елементів. При кожній відмові об'єкту, крім операцій $з$ ремонту, доводиться витрачати час на доставку резервного елемента зі складу. У такому випадку значення стаціонарного коефіцієнта готовності варто визначати за форм. 13.

$$
K_{\Gamma}(0)=\frac{T_{0}}{T_{0}+T_{p}+T_{\partial}}
$$

В іншому випадку, коли на об'єкті є будь-які резервні елементи в необмеженій кількості (негайно задовольняються всі вимоги), на відновлення витрачається мінімальний час, обумовлений лише часом ремонту. Тоді значення стаціонарного коефіцієнта готовності варто визначати за форм.14:

$$
K_{\Gamma}(\infty)=\frac{T_{0}}{T_{0}+T_{p}}
$$


Науковий вісник: Державне управління № 4(6)2020

Розглянемо математичну

модель

розрахунку раціонального за вартістю матеріального резерву об'єкту пожежно-технічного озброєння.

Метою розроблення математичної моделі розрахунку такого матеріального резерву (MP_O) $є$ можливість раціонального визначення рівня матеріального резерву для забезпечення запобігання та ліквідації надзвичайних ситуацій та їх наслідків на достатньому рівні при мінімальній вартості.

Для розробки математичної моделі розрахунку MP_O визначимо кількісний критерій рівня достатності резерву.

Для MP_О, як критерій достатності, можна застосувати коефіцієнт забезпеченості об'єкту озброєння $\left(\boldsymbol{K}_{3 \circ}(\boldsymbol{x})\right)$ при наявності у MP_O (x) елементів матеріального резерву (форм. 15).

Умови розрахунку MP_О наступні.

Об'єкт озброєння представлено послідовним з'єднанням різних працюючих елементів (m) типів по $\left(\boldsymbol{n}_{\boldsymbol{i}}\right)$ елементів $(i=1, m)$ кожного типу. В матеріалом резерві об'єкта озброєння для усіх працюючих елементів знаходяться $\left(\boldsymbol{x}_{\boldsymbol{i}}\right)$ резервних елементів, які являють собою резервований ланцюг 3 ненавантаженим резервом.

$$
K_{30}(x)=\frac{K_{\Gamma}(x)-K_{\Gamma}(0)}{K_{\Gamma}(\infty)-K_{\Gamma}(0)}
$$

де, $K_{\Gamma}(x)$ - стаціонарний коефіцієнт готовності;

$K_{\Gamma} \quad(0) \quad-\quad$ мінімальне значення стаціонарного коефіцієнта готовності об'єкту, що відповідає повній відсутності елементів у MP_O $(x=0)$;

$K_{\Gamma}(\infty) \quad-$ максимальне значення стаціонарного коефіцієнта готовності об'єкту, що відповідає необмеженому резерву елементів усіх типів у MP_O. 


$$
K_{\Gamma}(x)=\frac{1}{1+\sum_{i=1}^{m} \Delta_{i} T_{B i}+\sum_{i=1}^{m} \Delta_{i} T_{\not i} \cdot P_{i}\left(a_{i}, x_{i}\right)},
$$

де, $\sum_{i=1}^{m} n_{i} \lambda_{i}=\Delta-$ сума інтенсивностей відмов усіх працюючих елементів об'єкту;

$$
P_{i}\left(a_{i}, x_{i}\right)=P(x)=\Phi_{i}\left(a_{i}, x_{i}\right)-\left(x_{i} / a_{i}\right) \Phi_{i}\left(a_{i}, x_{i}+1\right)-
$$

імовірність простою об'єкту через відсутність резервних елементів $i$-го типу в МР_О, яка визначається через число елементів, середню витрату елементів і функцію Пуассона [8] 3 аргументами $\left(\boldsymbol{a}_{\boldsymbol{i}}, \boldsymbol{x}_{\boldsymbol{i}}\right)$;

$$
\begin{aligned}
& \boldsymbol{\phi}_{\boldsymbol{i}}\left(\boldsymbol{a}_{\boldsymbol{i}}, \boldsymbol{x}_{\boldsymbol{i}}\right)=\boldsymbol{e}^{-\boldsymbol{a}_{\boldsymbol{i}}-\text { диф. функ. Пуассона; }} \\
& \Phi_{i}\left(a_{i}, x_{i+1}\right)=1-e^{-a_{i}} \sum_{j=x_{i+1}}^{\infty} \frac{a_{i}^{j}}{j !}-\text { інтегр. функ. Пуассона; } \\
& a_{i}=\Delta_{i} t-\text { середнє число відмов елементів } i-\text { го }
\end{aligned}
$$

типу за час $t$;

$x_{i}$ - число резервних елементів $i$ - го типу у МР_O.

Надійність працюючих елементів характеризується постійною інтенсивністю відмов елементів $i$-го типу $\left(\lambda_{i}\right)$ i середнім часом відновлення об'єкту при відмові елемента i-го типу $\left(\boldsymbol{T}_{\boldsymbol{B} \boldsymbol{i}}\right)$.

Резервні елементи утворюють MP_О, який через період $\left(\boldsymbol{T}_{\boldsymbol{C}}\right)$, поповнюється до розрахункового рівня.

Якщо витрата резервних елементів протягом відрізка часу $\left(\boldsymbol{T}_{\boldsymbol{c}}\right)$ перевищує їх кількість в MP_О, то такий елемент потрібно доставити 3 найближчого складу. При цьому об'єкт виявляється в положенні простою, оцінюваного середнім часом доставки $\left(\boldsymbol{T}_{д i}\right)$.

Для прийнятої моделі, використавши зв'язок між показниками при експонентному законі надійності [8] ( $\boldsymbol{T}_{\boldsymbol{o}}=$ 
1 / М), та перетворивши формулу (12), стаціонарний коефіцієнт готовності об'єкту визначається форм. 16.

Стаціонарний коефіцієнт готовності $\left(\boldsymbol{K}_{\boldsymbol{\Gamma}}(\boldsymbol{x})\right)$ являє собою дискретну зростаючу функцію числа резервних елементів $(\boldsymbol{x})$. Якщо число резервних елементів $\left(\boldsymbol{x}_{\boldsymbol{i}}\right)$ взяти так, щоб додаткові ймовірності цих елементів мали однакову величину, то такий комплект стане раціональним по сумарному числу елементів $(\boldsymbol{x})$. Це значить, що критерієм для вибору числа елементів може служити рівність $\left(\Delta \boldsymbol{K}_{\boldsymbol{T}}\left(\boldsymbol{x}_{\boldsymbol{i}}\right)\right)=$ const.

Раціоналізація комплекту MP_O за вартістю забезпечується таким чином, щоб збільшення коефіцієнта готовності на одиницю вартості елементів $x_{i}$ мали б однакову величину. Тоді $\left(\Delta \boldsymbol{K}_{\boldsymbol{r}}\left(\boldsymbol{x}_{i}\right)\right)$ можна визначити за форм. 17.

$$
\Delta \mathrm{K}_{\Gamma \mathrm{i}}\left(\mathrm{x}_{\mathrm{i}}\right) \equiv \frac{\mathrm{T}_{\text {дi }} * \Phi\left(\mathrm{a}_{\mathrm{i}}, \mathrm{x}_{\mathrm{i}}\right)}{\mathrm{C}_{\mathrm{i}}}=\Phi_{\mathrm{O}}=\mathrm{cons} t
$$

де, $\Phi_{o}-$ довільне число, що характеризує приріст коефіцієнта готовності об’єкта.

$$
\Phi_{i}\left(a_{i}, x_{i}\right)=\frac{C_{i} * \Phi_{O}}{T_{\text {Дi }}}
$$

Методику розрахунку MP_О можна викласти наступним чином.

Вихідні дані для розрахунку:

1) заданий коефіцієнт забезпеченості $\left(\boldsymbol{K}_{3 о}\right)$ об'єкту MP_O;

2) число типів елементів (m) $(i=1, m)$;

3) середнє число відмов елементів кожного типу за період поповнення MP_O $\left(\boldsymbol{a}_{\boldsymbol{i}}\right)(i=1, m)$;

4) вартість елементів кожного типу $\left(\boldsymbol{C}_{\boldsymbol{i}}\right)$;

5) середній час відновлення об'єкту при відмові елементів кожного типу $\left(\boldsymbol{T}_{\boldsymbol{b}}\right)$;

6) середній час доставки резервних елементів $\left(\boldsymbol{T}_{\not i}\right)$; 
7) період поповнення МР-О у годинах $\left(\boldsymbol{T}_{\boldsymbol{c}}\right)$.

Порядок розрахунку.

1. Знаходимо максимальне й мінімальне значення стаціонарного коефіцієнта готовності об'єкту за форм. 19.

$$
\begin{gathered}
K_{\Gamma}(\infty)=\frac{1}{1+\sum_{i=1}^{m} \Delta_{i} T_{B i}}, \\
K_{\Gamma}(\mathrm{O})=\frac{1}{1+\sum_{i=1}^{m} \Delta_{i} T_{B i}+\sum_{i=1}^{m} \Delta_{i} T_{\not i}},
\end{gathered}
$$

2. Обираємо перше значення показника вартісної раціоналізації MP_О $\left(\boldsymbol{\Phi}_{1}\right)$. Його значення можна прийняти довільним, але мова йде про прирощення ймовірності, тому перше значення приймемо значно менш одиниці.

3. Знаходимо рівень показника раціоналізації для елементів першого типу по формулі (18) і значення $\left(\boldsymbol{x}_{\boldsymbol{1}}\right)$. Таким же чином знаходимо усі $\left(\boldsymbol{x}_{\boldsymbol{i}}\right)$ для $(i=1, \mathrm{~m})$.

4. Використовуючи формули $(12,15)$ знаходимо $\left(\boldsymbol{K}_{\boldsymbol{\Gamma}}(\boldsymbol{x})\right)$ та $\left(\boldsymbol{K}_{30}(\boldsymbol{x})\right)$.

5. Порівняємо отримане значення коефіцієнта забезпеченості із заданою величиною $K_{30}(x)<>K_{30}$.

Залежно від знака нерівності вибираємо нове значення для показника раціоналізації: якщо коефіцієнт забезпеченості виявився менш необхідного то рівень показника раціоналізації зменшують і навпаки.

6. Повторюємо дії п.п. 3,4 для нового значення показника раціоналізації.

Коли значення $\boldsymbol{K}_{3 \boldsymbol{o}}(\boldsymbol{x}) \approx \boldsymbol{K}_{\mathbf{3}} \mathbf{\pm 1} \boldsymbol{\mathbf { 1 }}$ р розрахунок закінчено.

Розраховані значення $\left(\boldsymbol{x}_{\boldsymbol{i}}\right)(i=1, \mathrm{~m})$ визначають раціональний за вартістю MP_O $\left(\boldsymbol{X}_{\boldsymbol{o}}\right)$ (форм.20). 
Науковий вісник: Державне управління № 4(6)2020

$$
\boldsymbol{X}_{O}=\sum_{i=1}^{m} \boldsymbol{x}_{i}
$$

де, $m$ - кількість типів елементів в МР_O

Математична модель розрахунку $M P_{-} \Gamma$.

Для MP_Г в якості критерію достатності використаємо коефіцієнт забезпеченості групи об'єктів одного типу озброєння матеріальними резервами (форм. 21).

$$
K_{3 Г}(x)=\frac{P_{Д}(x)-P_{д}(0)}{1-P_{Д}(0)} \cdot 100 \%
$$

де, $K_{3 Г}(x)$ - коефіцієнт забезпеченості групи об'єктів озброєння МР;

$P_{д}(x)$ - імовірність достатності, коли MP_Г містить х резервних елементів;

$$
P_{\text {д }}(0)=\prod_{i=1}^{m} e^{-a_{i}}-\text { імовірність достатності, коли у МР_Г }
$$

немає резервних елементів;

$m$ - число типів елементів в об'єкті озброєння;

$a_{i}=n_{i} * \lambda_{\mathrm{i}} * T_{P}-$ середнє число відмовних елементів, знайдених по числу працюючих елементів в усієї групі об'єктів $\left(\boldsymbol{n}_{\boldsymbol{i}}\right)$, інтенсивності відмов елементів і-го типу $\left(\boldsymbol{\lambda}_{\boldsymbol{i}}\right)$ та витратам ресурсу об’єкту $\left(\boldsymbol{T}_{\boldsymbol{P}}\right)$ за період поповнення MP_Г.

$$
P_{Д}(x)=\prod_{i=1}^{m} P_{Д i}\left(a_{i}, x_{i}\right)
$$

де , $P_{\not i}\left(a_{i}, x_{i}\right)=e^{-a_{i}} \sum_{j=0}^{x_{i}} \frac{a_{i}{ }^{j}}{j !}-$ імовірність достатності, коли MP_Г містить $\left(\boldsymbol{x}_{\boldsymbol{i}}\right)$ резервних елементів.

Працюючі елементи групи об’єктів озброєння разом 3 резервними елементами MP_Г можуть бути представлені статистично незалежними резервними ланцюжками. Тому ймовірність достатності $\left(\boldsymbol{P}_{\boldsymbol{\partial}}(\boldsymbol{x})\right)$ при послідовній схемі 
надійності елементів об'єкту, коли відмова елемента призводить до відмови об'єкту представимо формулою 22.

Типи та число запасних елементів у MP_Г повинні забезпечувати задане значення коефіцієнта забезпеченості або ймовірності достатності MP_Г.

Наше завдання полягає у находженні такого рішення про склад комплекту МР_Г, який би забезпечував задане значення коефіцієнта забезпеченості при мінімальній вартості. Таке рішення буде раціональним за вартістю.

Імовірність достатності $\left(\boldsymbol{P}_{\boldsymbol{L}}(\boldsymbol{x})\right)$ являє собою дискретну зростаючу функцію числа запасних елементів $(\boldsymbol{x})$. Прирощення ймовірності достатності $\left(\Delta \boldsymbol{P}_{\boldsymbol{i}}\left(\boldsymbol{a}_{i}, \boldsymbol{x}_{i}\right)\right) \in$ збитковою функцією, тобто внесок кожного наступного елемента у MP_Г зменшується, прагнучи при необмеженому збільшенні елементів до нуля. Якщо число запасних елементів $\left(\boldsymbol{x}_{\boldsymbol{i}}\right)$ взяти так, щоб додаткові ймовірності цих елементів мали однакову величину, то такий комплект стане раціональним по сумарному числу елементів $(\boldsymbol{x})$. Це значить, що критерієм для вибору числа в кожній групі може служити рівність $\left(\Delta \boldsymbol{P}_{\boldsymbol{j}}\left(\boldsymbol{a}_{i}, \boldsymbol{x}_{\boldsymbol{i}}\right)\right)=$ const. $\left(\Delta \boldsymbol{P}_{\boldsymbol{j}}\left(\boldsymbol{a}_{\boldsymbol{i}}, \boldsymbol{x}_{\boldsymbol{i}}\right)\right)$ можна визначити за форм. 23.

Два різних елементи 3 однаковим параметром надійності $\left(\boldsymbol{a}_{\boldsymbol{i}}\right)$ дадуть те саме збільшення ймовірності достатності, але ціна його буде залежати від вартості кожного 3 елементів. Тому умова раціоналізації за вартістю комплекту МР повинно бути сформульоване так: кількість запасних елементів вибираються таким чином, щоб збільшення ймовірності достатності комплекту МР на одиницю вартості елементів $\left(\boldsymbol{C}_{\boldsymbol{i}}\right)$ мали б однакову величину $Y_{i}\left(a_{i}, x_{i}\right) / C_{i} \approx Y_{c}$ - const.

$$
\Delta P_{\partial i}\left(a_{i}, x_{i}\right)=\phi p_{i}\left(a_{i}, x_{i}\right) /\left(1-\Phi\left(a_{i}, x_{i}\right)\right)=Y_{i}\left(a_{i}, x_{i}\right)
$$

де, $\Delta P_{\partial i}\left(a_{i}, x_{i}\right)$ - прирощення ймовірності достатності;

$$
\begin{aligned}
& \phi_{i}\left(a_{i}, x_{i}\right)=e^{-a_{i}}-\text { диферент. функц. Пуассона; } \\
& \Phi_{i}\left(a_{i}, x_{i}\right)=1-e^{-a_{i}} \sum_{j=x_{i}}^{\infty} \frac{a_{i}^{j}}{j !}
\end{aligned}
$$


Науковий вісник: Державне управління № 4(6)2020 елементів.

$Y_{i}\left(a_{i}, x_{i}\right)$ - показник раціоналізації для $i$-го типа

Тепер раціоналізацію, за сумарною кількістю елементів $\boldsymbol{x}$, забезпечить умова $Y_{i}\left(a_{i}, x_{i}\right)=Y$ - const.

Методику розрахунку комплекту МР_Г можна викласти наступним чином.

Вихідні дані для розрахунку:

1) заданий коефіцієнт забезпеченості групи систем MP_Г при визначеній точності - $\left(\boldsymbol{K}_{3 \Gamma} \mathbf{\pm 1 \%}\right)$ (відсоток визначає замовник MP_Г);

2) кількість типів елементів в об'єктах озброєння - (m);

$3)$ середня витрата елементів кожного типу $\left(\boldsymbol{a}_{\boldsymbol{i}}\right)(\mathrm{i}=1, \mathrm{~m})$;

4) вартість елементів кожного типу $\left(\boldsymbol{C}_{\boldsymbol{i}}\right)(\mathrm{i}=1, \mathrm{~m})$.

Порядок розрахунку:

1. Вибираємо перше значення показника раціоналізації MP_Г $-\left(\boldsymbol{Y}_{\boldsymbol{c}}{ }_{\boldsymbol{c}}\right)$ Його значення можна прийняти довільним. Але мова йде про ймовірнісне значення, до того ж помножене на вартість елементів. Перше значення приймемо, наприклад:

$$
Y_{c}^{1}=10^{-3}
$$

2. Визначаємо рівень показника оптимізації для елемента першого типу виходячи $з$ того, що $Y_{c l}\left(a_{1}, x_{1}\right)=Y_{c}^{l} * C_{1}$

3. За відомими середньому числу відмовних елементів першого типу $\left(\boldsymbol{a}_{1}\right)$ та рівню оптимізації $\left(\boldsymbol{Y}_{\boldsymbol{c} 1}\left(\boldsymbol{a}_{1}, \boldsymbol{x}_{!}\right)\right)$, використав формулу (23), знаходимо число запасних елементів першого типу $\left(\boldsymbol{x}_{\boldsymbol{1}}\right)$.

4. Виконуючи пункти 2,3 для $(\mathrm{i}=1, \mathrm{~m})$, знаходимо $\left(\boldsymbol{x}_{\boldsymbol{i}}\right)$ для $(\mathrm{i}=1, \mathrm{~m})$.

5. За $\left(\boldsymbol{a}_{\boldsymbol{i}}, \boldsymbol{x}_{\boldsymbol{i}}\right)$ розраховуємо $\left(\boldsymbol{P}_{\text {Дi }}\left(\boldsymbol{a}_{\boldsymbol{i}}, \boldsymbol{x}_{\boldsymbol{i}}\right)\right), \quad$ використовуючи пояснення формули (22) для $(\mathrm{i}=1, \mathrm{~m})$.

6. За формулами $(21,22)$ знаходимо $\left(\boldsymbol{P}^{\boldsymbol{l}} \boldsymbol{д}(\boldsymbol{x})\right)$ т а $\left(\boldsymbol{K}^{\mathbf{1}} \boldsymbol{}_{\boldsymbol{\Gamma}}(\boldsymbol{x})\right)$ та порівнюємо з заданим показником $\left(\boldsymbol{K}_{3 \Gamma}\right)$.

Залежно від знаку порівняння зменшуємо або збільшуємо показник раціоналізації і виконуємо розрахунки за пунктами 1-6 методики. 
Науковий вісник: Державне управління № 4(6)2020

Коли значення $\left(\boldsymbol{K}^{\mathbf{1}}{ }_{\boldsymbol{3}}(\boldsymbol{x}) \approx \boldsymbol{K}_{3 \Gamma} \mathbf{\pm 1 \%}\right)$, розрахунок закінчено.

Розраховані значення $\left(\boldsymbol{x}_{\boldsymbol{i}}\right)(\mathrm{i}=1, \mathrm{~m})$ дають наш раціональний за вартістю 3ІП_Г.

$$
X_{\Gamma}=\sum_{i=1}^{m} x_{i}
$$

де, $m$ - кількість типів елементів в MP_Г.

Висновки та напрями подальших досліджень. Розробка та корегування інструменту механізмів управління ЄДСЦЗ виступає як головна передумова підвищення ефективності управлінського процесу. Важливим компонентом є підготовка та прийняття обгрунтованих управлінських рішень щодо запобігання та подолання наслідків надзвичайних ситуацій. Ефективність функціонування ЄДСЦЗ в цілому визначається оперативністю дій сил цивільного захисту та наявності необхідних матеріальних резервів.

Тривалість проведення різного виду робіт залежить від достатнього запасу матеріального резерву, що використовується при виконанні робіт, та визначає час ліквідації НС та їі наслідків, тим самим впливає на кількість людських жертв і об'єм матеріальних збитків від НС.

Пропонована математична модель дозволяє оцінити готовність об’єкту озброєння та підрозділу сил ЦЗ від забезпеченості матеріальними резервами, а також визначити загальні об’єми складського матеріального резерву MP_C, раціонального за вартістю об'єму матеріальних резервів об'єкту озброєння МР-О та групи об'єктів МР-Г з метою забезпечення функціонування сил цивільного захисту на достатньому (заданому) рівні готовності..

Складність розрахунків визначає необхідність використання комп'ютерної техніки при реалізації цих методик. Тому подальшим напрямом наукових досліджень 3 
Науковий вісник: Державне управління № 4(6)2020

даної проблематики вбачається розробка комп'ютерних програм розрахунку різних видів матеріальних резервів.

\section{Список використаних джерел}

1. Кодекс цивільного захисту України: Закон України від 02.10.2012№ 5403-6 // База данних «Законодавство України / ВР України. URL : https://zakon.rada.gov.ua/laws/show/5403-17\#Text (дата звернення 20.10.2020).

2. Про затвердження Порядку створення та використання матеріальних резервів для запобігання і ліквідації наслідків надзвичайних ситуацій : Постанова Кабінету Міністрів України від 30.09.2015 р. № 775 // База даних «Законодавство України»/ BP України. URL : https://zakon.rada.gov.ua/laws/main/775-2015\%D0\%BF (дата звернення 20.10.2020).

3. ДСТУ 2860-94. Надійність техніки. Терміни та визначення. [Чинний від 1996-01-01]. К. : Держстандарт України, 1994. 29 с.

4. Аналітичний огляд стану техногенної та природної безпеки в Україні за 2018 рік. 2019. УкрНДІЦЗ, 448 с.

5. Федорчак О. Класифікація механізмів державного управління. Демократичне врядування. Науковий вісник. 2008. Вип. 1. C. $1-11$.

6. Єлісєєв В. Н. Показники залежності ефективності функціонування підрозділів сил цивільного захисту від забезпеченості матеріальними резервами. Проблеми цивільного захисту: управління, попередження, аварійно-рятувальні та спеціальні роботи: тези доп. III Всеукраїн. наук.-практ. конф., 02 жовтня 2015. Харків : НУЦЗУ. С. 95-97.

7. Методичні рекомендації посадовим особам центральних органів виконавчої влади щодо реалізації завдань у сфері цивільного захисту: посібник / Бондаренко О. О. та ін.. URL : http://library.iducz.dsns.gov.ua/weblib/books/Bondarenko\%20O_O/M et rek 2017.pdf (дата звернення : 20.10.2020).

8. Вентцель Е. С. Теория вероятностей : монографія. М.: Наука, 1969. $578 \mathrm{c}$.

9. Єлісєєв В. Н., Попов Л. В. Показники залежності ефективності функціонування підрозділів оперативно-рятувальної служби 
цивільного захисту від забезпеченості матеріальними резервами. Науковий збірник ІДУЦЗ. 2013. № 1. С. 27-32.

10. Методичні рекомендації щодо створення та використання матеріальних резервів для запобігання і ліквідації наслідків надзвичайних ситуацій. К. : ДСНС України. 2017. 97 с.

11. Статистична інформація Державної служби статистики України // Вебсайт Держ.служби статистики / Державна служба статистики України. URL : http://www.ukrstat.gov.ua/ (дата звернення : 20.10.2020).

\section{References}

1. Kodeks tsyvilnoho zakhystu Ukrainy [Code of civil defence of Ukraine].

(2020,

lypnia 22).

URL https://zakon.rada.gov.ua/laws/show/5403-17\#Text [in Ukrainian].

2. Postanova Kabinetu Ministriv Ukrainy Pro zatverdzhennia Poriadku stvorennia ta vykorystannia materialnykh rezerviv dlia zapobihannia i likvidatsii naslidkiv nadzvychainykh sytuatsii " [Resolution of the Cabinet of Ministers of Ukraine "On approval of the Procedure for the creation and use of material reserves for the prevention and elimination of the consequences of emergencies"] (n.d.) zakon.rada.gov.ua Retrieved from https://zakon.rada.gov.ua/laws/main/775-2015-\%D0\%BF [in Ukrainian].

3. DSTU 2860-94. Nadiinist tekhniky. Terminy ta vyznachennia. Vymohy [Reliability of equipment. Terms and definitions]. from 1 January 1996. Kyiv : Derzhstandart Ukrainy, 1994. [ in Ukrainian].

4. Analitychnyi ohliad stanu tekhnohennoi ta pryrodnoi bezpeky $\mathrm{v}$ Ukraini za 2018 rik [Analytical review of the state of man-made and natural security in Ukraine in 2018]. 2019. UkrNDITsZ, S. 448. [ in Ukrainian].

5. Fedorchak O. Klasy`fikaciya mexanizmiv derzhavnogo upravlinnya [Classification of mechanisms of public administration]. «Demokraty`chne vryaduvannya». Naukovy`j visny`k. Vy`pusk 1. 2008. s. 1-11. [ in Ukrainian].

6. Yelisieiev V. N. (2015), Pokaznyky zalezhnosti efektyvnosti funktsionuvannia pidrozdiliv syl tsyvilnoho zakhystu vid zabezpechenosti materialnymy rezervamy. [Indicators of the 
Науковий вісник: Державне управління № 4(6)2020

dependence of the effectiveness of the units of civil defense forces on the provision of material reserves] Proseedings from III Vseukrainska naukovo-phaktychna ronferensiia. "Problemy tsyvilnoho zakhystu: upravlinnia, poperedzhennia, avariino-riatuvalni ta spetsialni roboty» $\mathrm{m}$. Kharkiv NUTsZU [ in Ukrainian].

7. Bondarenko O. O., and al. Metodychni rekomendatsii posadovym osobam tsentralnykh orhaniv vykonavchoi vlady shchodo realizatsii zavdan u sferi tsyvilnoho zakhystu: posibnyk [Methodical recommendations to officials of the central bodies of executive power on the implementation of tasks in the field of civil protection] (n.d.) lsbrary.iducz.dsns.gov.ua URL : https://cutt.ly/JhuXnYP [in Ukrainian].

8. Venttsel E. S. (1969) Teoryia veroiatnostei [Theory of probabilities] M: Nauka.

9. Yelisieiev V. N. \& Popov L. V. (2013) Pokaznyky zalezhnosti efektyvnosti funktsionuvannia pidrozdiliv operatyvno-riatuvalnoi sluzhby tsyvilnoho zakhystu vid zabezpechenosti materialnymy rezervamy. [Indicators of dependence of efficiency of functioning of divisions of operative-rescue service of civil protection on provision with material reserves]. Naukovyi zbirnyk IDUTsZ - Scientific collection of IDUCZ 1, 27-32. [ in Ukrainian].

10. Metodychni rekomendatsii shchodo stvorennia ta vykorystannia materialnykh rezerviv dlia zapobihannia i likvidatsii naslidkiv nadzvychainykh sytuatsii [Methodical recommendations on the creation and use of material reserves to prevent and eliminate the consequences of emergencies]. - Kyiv. : DSNS Ukrainy. [ in Ukrainian].

11. Statystychna informatsiia Derzhavnoi sluzhby statystyky Ukrainy (n.d.) ukrstat.gov.ua URL : http://www.ukrstat.gov.ua [ in Ukrainian]. 


\title{
METHOD OF CALCULATION OF MATERIAL RESERVES AS AN TOOL OF THE MECHANISM OF PUBLIC MANAGEMENT OF CIVIL PROTECTION FORCES
}

Yelisieiev Valerii, Cand. of Sc. (Eng.), Assoc. Prof., Lecturer of the Department of Fire Prevention and Life Safetv. tel. : +380672491527, e-mail: elisev1941@ukr.net, https://orcid.org/0000-0002-2427-0860

Pruskyi Andrii, Cand. of Sc. (Eng.), Assoc. Prof., Head of the Department of Fire Prevention and Life Safetv. tel. :+380979480488, e-mail: prusskiy@ukr.net, https://orcid.org/0000-0002-9132-7070

Tvshchenko Vasvl. Associate Professor of the Department of Fire Prevention and Life Safetv. Candidate of Sciences in Public Administration. Associate Professor +380502156456, e-mail: tva_5555@ukr.net, https://orcid.org/0000-0001-7505-1599

Vlasenko Yevhen. Senior Lecturer of the Department of Fire Prevention and Life Safety, +380679615878, e-mail: geniy20091@ukr.net, https://orcid.org/0000-0002-9619-1504

Institute of Public Administration and Research in Civil Defense

\begin{abstract}
Training and taking reasonable managerial decisions is an important element of administration activitv. The efficiency of the singe state svstem of civil protection in general depends on the prompt actions of civil protection forces. The civil protection forces consist of emergencv-rescue formations. specialized services and other civil protection formations aimed for emergencvrescue and other urgent works in emergency mitigation. Duration of different works depends on the sufficient reserves of materials used for works. and defines the time of emergencv response and its conseauences. and so influence the quantity of human losses and amount of material losses due to emergency. The scientific article proposes a mathematical scheme for definition of necessary (sufficient) material reserves in order to improve the efficiency of actions of civil protection subdivisions during the emergencv mitigation based on the analvsis of the tasks defined by the Civil Protection Code as well as the actions of government agencies and civil protection forces in emergencies. Material reserves needed to provide the exploitation and repairing of the hardware and weapon mav form the sets of material reserves or material reserves bv individual tvpes of elements at stocks. Constituent parts of material reserves mav be in their turn divided into obiect (for one tvpe of hardware) and group ones (for the group of hardware obiects of similar tvpe). The article develops the mathematical scheme of calculation of material reserves needed for provision equipment and weapons exploitation during emergencv-rescue and other tvpes of works. We use some indexes of weapon reliability to assess the influence of material reserves on efficiencv of civil protection subdivisions during the emergency response and its consequences.
\end{abstract}

Kev words: civil protection forces. calculation method, material reserves, availability index, weapons object, probability. 